LL난, BANCO CENTRAL DO BRASIL

Is There Help Indeed, if There is Help in Need? The case of credit unions during the global financial crisis

Leila Aghabarari, Andre Guettler, Mahvish Naeem and Bernardus Van Doornik

January 2020

Working Papers
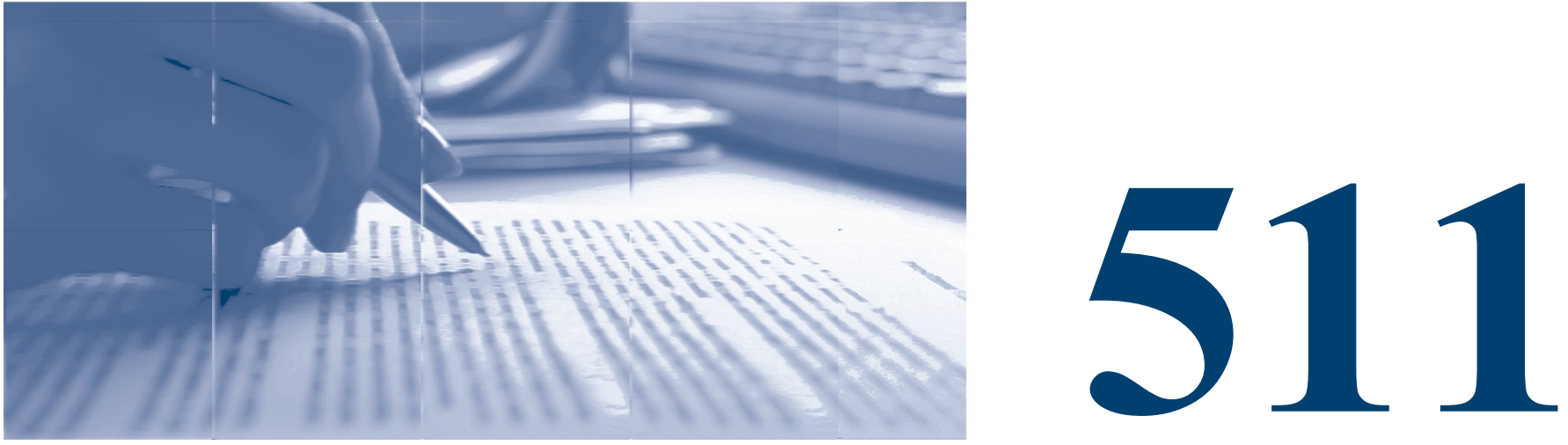
ISSN 1518-3548

CGC 00.038.166/0001-05 


\section{Working Paper Series}

Edited by the Research Department (Depep)-E-mail: workingpaper@bcb.gov.br

Editor: Francisco Marcos Rodrigues Figueiredo

Co-editor: José Valentim Machado Vicente

Head of the Research Department: André Minella

Deputy Governor for Economic Policy: Fabio Kanczuk

The Banco Central do Brasil Working Papers are evaluated in double blind referee process.

Although the Working Papers often represent preliminary work, citation of source is required when used or reproduced.

The views expressed in this Working Paper are those of the authors and do not necessarily reflect those of the Banco Central do Brasil.

As opiniões expressas neste trabalho são exclusivamente do(s) autor(es) e não refletem, necessariamente, a visão do Banco Central do Brasil.

\section{Citizen Service Division}

Banco Central do Brasil

Deati/Diate

SBS - Quadra 3 - Bloco B - Edifício-Sede $-2^{\circ}$ subsolo

70074-900 Brasília - DF - Brazil

Toll Free: 08009792345

Fax: +55 (61) 3414-2553

Internet: http//www.bcb.gov.br/?CONT ACT US 


\section{Non-technical Summary}

Financial crises can adversely impact the real economy through deterioration of the outcomes of bank-dependent firms. If all financial institutions react to a financial shock with the same intensity, economic consequences of the credit crunch may be irreversible. Empirical evidence suggests that a diversified banking industry could cope better with a financial crisis. However, when studying the GFC, most recent empirical work has focused mainly on bank lending behavior. Conversely, we explore credit unions (CUs), which are prototypical relationship lenders to retail clients and small and medium enterprises (SMEs). CUs may respond to a financial crisis differently than other types of banks because of their unique membership-based governance structure. CUs are not driven only by profit maximization but are also interested in alleviating credit constraints given their cooperative nature. Thus, any reduction of credit supply may be less pronounced (insurance effect).

We study the transmission of liquidity shocks in the Brazilian banking market using the GFC as a natural laboratory. We examine whether CUs continue providing loans to the firms during the financial crisis and whether this cushion transmits to the real economy. We find evidence for an insurance effect of CUs given that they decreased their lending volume to a smaller extent during the GFC compared to other types of banks. Moreover, compared to non-CUs, CUs provided credit with longer maturities and required less collateral. However, these relaxed credit conditions came at a cost: $\mathrm{CU}$ members paid higher interest rates, and the CUs faced higher future default frequencies. Nonetheless, compared to non-CUs, CUs seem to support their clients via credit supply during dire times.

We further provide evidence that insurance effect of CUs is transmitted to the labor market. Micro firms that had higher loans from the CUs before the crisis increased employment and paid more in wages during the crisis period. The positive real effects diminish as the firm

size increases. Our findings reinforce the importance of CUs for small businesses, which are of vital importance for job creation and economic growth. Overall, owing to their non-cyclical behavior during the crisis, CUs appear to be able to mitigate the propagation of negative shocks of the financial crisis to the real economy. 


\section{Sumário não-técnico}

Crises financeiras podem afetar adversamente a economia real por meio da deterioração dos resultados das empresas que dependem de bancos. Se todas as instituições financeiras reagem a um choque financeiro com a mesma intensidade, as consequências econômicas da crise de crédito podem ser irreversíveis. Evidências empíricas sugerem que um setor bancário diversificado poderia lidar melhor com uma crise financeira. No entanto, trabalhos empíricos mais recentes sobre a crise financeira de 2008/09 concentraram-se principalmente no comportamento dos empréstimos bancários. Em contraste, analisamos as cooperativas de crédito (CCs), que são um arquétipo de relacionamento como emprestadores para clientes de varejo e pequenas e médias empresas (PMEs). As CCs podem responder a uma crise financeira de maneira diferente de outros tipos de bancos, devido à sua singular estrutura de governança baseada em associação. As CCs não são impulsionadas apenas pela maximização das sobras, mas também buscam atenuar restrições de crédito, em função de sua natureza cooperativa. Assim, qualquer redução na oferta de crédito pode ser menos pronunciada (efeito seguro).

Nós analisamos a transmissão de choques de liquidez no mercado bancário brasileiro utilizando a crise financeira de 2008/09 como um laboratório natural. Verificamos se as CCs seguiram fornecendo empréstimos às empresas durante a crise financeira e se esse suporte se transmitiu à economia real. Encontramos evidências de um efeito seguro das CCs, uma vez que elas diminuíram seu volume de empréstimos em menor escala durante a crise de 2008/09, quando comparadas com outros tipos de bancos. Além disso, em comparação com as não-CC, as CCs forneceram crédito com vencimentos mais longos e exigiram menos garantias. No entanto, essas condições de crédito relaxadas tiveram um custo: os membros da CCs pagaram taxas de juros mais altas e as CCs enfrentaram maior frequência de inadimplência futuras. Em comparação com as não-CCs, as CCs parecem dar suporte aos seus clientes por meio da oferta de crédito durante períodos difíceis.

Adicionalmente, fornecemos evidências de que o efeito seguro das $\mathrm{CC}$ foi transmitido ao mercado de trabalho. As microempresas que tinham empréstimos mais altos das $\mathrm{CC}$ antes da crise criaram mais emprego e pagaram melhores salários durante o período de crise. Os efeitos reais positivos diminuem à medida que o tamanho da empresa aumenta. Nossos resultados reforçam a importância das CCs para as pequenas empresas, que são de vital importância para a criação de empregos e para o crescimento econômico. No geral, devido ao seu comportamento não cíclico durante a crise, as CCs parecem ser capazes de mitigar a propagação de choques negativos da crise financeira para a economia real. 


\title{
Is There Help Indeed, if There is Help in Need? the case of credit unions during the global financial crisis
}

\begin{abstract}
Leila Aghabarari ${ }^{\dagger}$
Andre Guettler

Mahvish Naeem ${ }^{\S}$

Bernardus Van Doornik**

Credit unions (CUs) may respond to a financial shock differently than other types of banks because of their unique membership-based governance structure. We exploit the financial crisis of 2008/09 as a negative shock to Brazilian banks and analyze the lending behavior of CUs versus those of non-CUs and the subsequent effects on the commercial clients' labor force. We find evidence that during the financial crisis, CUs tightened access to credit to their members to a lesser extent (insurance effect) than did other bank types. Moreover, compared to non-CUs during the crisis, CUs provided credit with longer maturities and required less collateral, albeit at higher interest rates. Notwithstanding, CUs did not display higher level of non-performing loans on their credit portfolios in comparison to other banks in the crisis period. However, CUs faced relatively higher future default frequencies. Notably, the labor market impact of the insurance effect of CUs is positive for very small firms in the form of an increase in employment and wages in the crisis period.
\end{abstract}

Keywords: Credit unions, Financial intermediaries, Financial crisis, Relationship lending, Labor market outcomes

JEL: G01, G21, J21, J31

The Working Papers should not be reported as representing the views of the Banco Central do Brasil. The views expressed in the papers are those of the author(s) and do not necessarily reflect those of the Banco Central do Brasil, International Bank for Reconstruction and Development/World Bank and its affiliated organizations, or those of the Executive Directors of the World Bank or the governments they represent.

\footnotetext{
${ }^{\dagger}$ World Bank Group, 1818 H St NW, Washington DC, 20433. E-mail: laghabarari@ worldbankgroup.org.

$\$$ Ulm University, Institute of Strategic Management and Finance, Helmholtzstraße 22, $89081 \mathrm{Ulm}$, Germany and Institute for Economic Research Halle (IWH), E-mail: andre.guettler@uni-ulm.de (corresponding author).

${ }^{\S}$ Ulm University, Institute of Strategic Management and Finance, Helmholtzstraße 22, 89081 Ulm, Germany, Email: mahvish.naeem@uni-ulm.de.

** Central Bank of Brazil, Research Department, Setor Bancário Sul Quadra 3 Bloco B - Ed. Sede, CEP: 70074-900 Brasília, Brazil, E-mail: bernardus.doornik@bcb.gov.br.

Declarations of interest: none
} 


\section{Introduction}

Bank financing is a crucial source of funding for businesses. Hence, disruptions in bank lending activity can be the cause of adverse shocks to the real economy. When a financial crisis unfolds, access to finance tightens because banks cut back credit supply. This reduction can adversely affect growth. Financial crisis has impact on the real economy largely through deterioration of the outcomes of bank-dependent firms (e.g., Hoshi and Kashyap, 1990; Morck et al., 2001; Bayoumi and Lipworth, 1999; Chava and Purnanandam, 2011; Paravisini, 2008).

If all financial institutions react to a shock with the same intensity, the economic consequences of the credit crunch can be irreparable. However, there is empirical evidence that, during a crisis, some types of banks curtail their lending less than others. For example, government-owned banks increase the supply of credit compared to private banks, which decrease lending during the crisis (Coleman and Feler, 2015). Additionally, financial constraints are more likely to be prevalent among local banks compared to foreign banks (Paravisini, 2008). Hence, the literature provides evidence that a diversified banking industry could cope better with a financial crisis.

Most recent empirical work has focused on bank lending behavior during the global financial crisis (GFC) of 2008/09. However, alternative financial institutions have received little academic attention. We attempt to fill the gap in this literature by exploring credit unions (CUs), as they are different in terms of governance and ownership structure. We study the transmission of liquidity shocks in the Brazilian banking market using the financial crisis of 2008/09 as a natural laboratory. We examine whether CUs can provide countercyclical support during a financial crisis and whether this comfort transmits to the real economy. 
Our focus is on CUs because they are prototypical local lenders to retail clients and small and medium enterprises (SMEs). The peculiarity of CUs concerns their cooperative nature. These intermediaries collect deposits from their members and provide their members with asset transformation into loans. Each member has one vote regardless of the volume of equity they have invested in the CU. Thus, any reduction of credit supply during dire times may be less pronounced in CUs given that members not only are driven by profit maximization of their equity investment but are also interested in attractive loan terms and alleviating credit constraints (Angelini, Di Salvo, and Ferri, 1998). Compared to non-CUs, we thus expect CUs to cut back less on lending during the financial crisis (insurance effect). On the other hand, CUs' membership-based ownership also features a potential disadvantage in that members can walk away during distressing times and hence decrease the CUs' capital base. Thus, even though a CU might prefer to keep lending volume high, it might not be able to do so because of the lack of capital (equity effect). Which of the two forces dominate is an open empirical question that we analyze in this paper.

To investigate the lending behavior of CUs compared to non-CUs, we need to address two identification challenges. First, we must find an aggregate adverse shock to the whole financial system. We choose the GFC in Brazil as an aggregate shock to overcome this challenge. Our second and main identification challenge is the simultaneous nature of credit supply and credit demand. After an aggregate shock, financial intermediaries and businesses are affected at the same time. This implies that financial intermediaries might reduce credit supply and at the same time firms might demand less credit. We need to design a model that is able to disentangle bank credit supply from firm credit demand. Our data has the advantage of allowing us to address this identification challenge. We use an extensive credit registry dataset provided by the Central Bank of Brazil (BCB) that covers the whole financial system. Our data allows us to use multiple bank- 
firm relationships, which means we can track the loans of the same firm from different banks at the same time. The data are on the firm-bank-quarter level, which permits investigating the impact on the intensive margin of the same firm at the same point in time from CUs versus non-CUs. We are able to control for demand shocks at the firm level by using firm-time fixed effects. Besides, we control for other time-invariant determinants of credit supply at the bank level and for unobserved cross-sectional heterogeneity at the firm-bank level. Our model enables us to assess how CUs changed their lending volume during the crisis compared to non-CUs.

We find evidence for an insurance effect of CUs given that they decreased their lending volume to a smaller extent during the GFC compared to other bank types. CUs also required less collateral and offered longer maturities compared to non-CUs. However, these relaxed credit conditions came at a cost: $\mathrm{CU}$ members paid higher interest rates, and the CUs faced higher future default frequencies. We further find evidence of the importance of the banks' equity ratio. During the crisis, the CUs' equity was lower compared to non-CUs, they provided larger loans compared to non-CUs. Thus, we conclude that the insurance effect dominates the equity effect of CUs. Overall, we show that CUs with their distinct membership and ownership structure provide insurance to their members. The insurance effect seems to limit the propagation of adverse liquidity shocks to the real economy via credit supply.

Next, we study whether the insurance effect of CUs transmits to the labor market. Financial crisis hinders firms' economic activities. This leads to downsizing of business and workforce, which amplifies the real economic consequences of the crisis. We ask whether CUs' insurance effect can keep firms from discharging their employees or cutting back on their wages, thus limiting the propagation of a negative shock to the labor market. For this part of our analysis, we use the Annual Social Information System (RAIS) dataset that contains the firm-level data for the 
Brazilian labor market. Small and medium firms are more vulnerable to credit market frictions during the financial crisis than their larger counterparts (Albertazzi and Marchetti, 2010; Iyer et al., 2010; Jimenez et al., 2009). Not only is it difficult for these firms to get bank loans, but they also suffer from lack of access to alternative funding sources. CUs are a crucial source of funding for these types of firms. We explore this particular financing relationship because these small enterprises are of vital importance for job creation and economic growth. We find evidence that the micro firms with higher pre-crisis outstanding loans from CUs increased employment and paid more in wages during the crisis period. The positive real effects diminish as the firm size increases. This result reinforces the importance of CUs for small businesses.

Our paper is connected to several strands of the literature. First, we contribute to the literature regarding the diverse reactions of different banks to the financial crisis. Given the uneven reaction of distinct bank types to the same shock, a diversified banking industry could alleviate the trauma of financial crisis to some extent. Coleman and Feler (2015) show that the governmentowned banks in Brazil helped mitigate the crisis by increasing supply of credit compared with private banks, which decreased lending during the crisis. Additionally, financial constraints are more likely to be prevalent among local banks, as unlike large foreign banks, these do not have significant internal capital markets from which to draw funding (Paravisini, 2008). We add to this stream of literature by comparing the CUs' reaction to financial crisis with that of other bank types.

Second, our paper relates to studies regarding the banking relationship and its effect on credit availability. The studies mostly imply that a stronger relationship helps overcome information asymmetries, which is associated with better access to credit for businesses (e.g., Cole 1998; Elsas and Krahnen, 1998; Machauer and Weber, 2000). Cole (1998) presents empirical evidence that banking relationships provide private information about the financial prospects of 
the financial institutions' borrowers. He finds that a potential lender is more likely to extend credit to a firm with which it has a pre-existing relationship as a source. Additionally, Berlin and Mester (1998) and Ferri and Messori (2000) show that stronger relationships offer a better protection (insurance) to borrowers against interest rate cycles. Mian (2006) addresses the importance of information and agency costs for lending. He finds that information costs can cause foreign banks to stay away from lending to soft information firms. Petersen and Rajan (1994) provide evidence that the availability of finance from institutions increases as the ties between a firm and its creditors tighten. The most related paper is Angelini, Di Salvo, and Ferri (1998). They use Italian survey data and show that the cooperative ownership of CUs differentiates them from other types of banks because their members enjoy easier access to credit, unlike non-member customers. We extend this literature by investigating the novel role of CUs as liquidity providers during the financial crisis. Our empirical strategy is better suited to controlling for demand effects compared to Angelini, Di Salvo, and Ferri (1998).

Third, we contribute to the strand of the empirical banking literature that uses within firm estimation to disentangle supply from demand. Jiménez and Ongena (2012) use loan application data from the credit register of the Bank of Spain to show that firms that borrow from more than one bank at the same time with different balance sheet strengths experience different lending constraints after a change in short-term interest rates. Jiménez et al. (2014) use the same data to compare changes in lending of the various banks to the same firms in the same month. They show that a lower interest rate induces lowly capitalized banks to take higher risk in their lending than highly capitalized banks. Khwaja and Mian (2008) use loan-firm-level data to show that after an immediate uneven shock to the funding of the banks in Pakistan, the same firm's loan growth from one bank changes relative to its loan from another bank that was more exposed to the shock. Using 
a similar within firm comparison strategy, Schnabl (2012) shows that domestic and foreign ownership of banks matters for the transmission of liquidity shocks. After the Russian debt default and its transmission to Peru, Peruvian domestic banks reduced their lending to their borrowers more than foreign-owned banks. We extend this literature by comparing the CUs' potential to mitigate macro shocks with other non-membership-based bank types.

Fourth, our paper relates to the literature on the diversity-diversification trade-off. Wagner (2011) shows that, when all investors hold similar assets because of portfolio diversification, the probability of individual failure decreases. However, they face joint liquidation risk, which is costly and increases the likelihood of a systemic crisis. The paper thus argues that diversity is important for financial sector stability. We extend this literature by studying CUs as they enhance the diversity of the financial sector.

Finally, we contribute to the literature that investigates the impact of credit supply shocks on the real economy (e.g., Peek and Rosengren, 2000; Ashcraft, 2005; Khwaja and Mian, 2008; Schnabl, 2012; Chodorow-Reich, 2014; Benmelech, Bergman, Seru, 2015). Hoshi and Kashyap (1990), Morck, Nakamura, and Frank (2001), and Bayoumi and Lipworth (1999) suggest that the Japanese economic problems of the recent past are at least partially due to the disruptions in bank lending that began in the early 1990s. Chava and Purnanandam (2011) provide evidence that bankdependent firms face adverse valuation consequences when the banking sector's financial health deteriorates. Moreover, Paravisini (2008) documents that shocks to the banking sector can have a disproportionate effect on investment by local bank borrowers in emerging markets. However, there remains a lack of research on the influence of different bank-firm relationships on the labor market. We attempt to fill this gap in the literature by considering the employment and wage outcomes of small firms with CU lending relationships. 


\section{Institutional Background}

CUs (Credit Unions or Credit Cooperatives) are depository institutions, which provide credit and financial services to their members. Historically, CUs were founded to provide financial services to farmers, (small) firms, and poorer households, which were not covered by traditional banks. There are two principal characteristics of CUs that make them distinct from other types of banks. First, in a CU, the members are both the owners of the organization and its customers. This characteristic stands in sharp contrast to private commercial banks, which are privately owned for example. Savings banks often have public ownership (e.g., in Germany, see Hackethal, 2004) or at least close ties to local governments. Second, in a CU, the membership provides both the demand for and supply (by equity and deposits) of loanable funds. ${ }^{5}$

In recent years, the number of loans and services provided by CUs and cooperative banks to their members has been increasing. According to a report by the WOCCU (World Council of Credit Unions), in 2015, more than 60,500 CUs were operational in 109 countries with assets of 1.8 trillion US dollars in aggregate. The loans provided by CUs were 1.2 trillion US dollars in aggregate, with a total of approximately 223 million members worldwide. ${ }^{6}$

The first CU in Latin America was founded in Brazil in 1902. The number of CU members in Brazil from 2005 to 2015 increased from 2.6 million to 7.8 million individuals. Over the last 30 years in Brazil, the number and assets of CUs have increased significantly. The net worth, assets, deposits, and credit operations in Brazilian CUs have been growing since 2000. As of the year 2015, the network of these CUs represented approximately $20 \%$ of bank branches in Brazil. ${ }^{7}$

\footnotetext{
${ }^{5}$ By law, CUs are only allowed to accept deposits and grant loans to their members in Brazil.

${ }^{6}$ World council of credit unions, 2016.

${ }^{7}$ Portal do cooperativismo de credito.
} 
CUs have an important role in the Brazilian financial system. They mainly serve the otherwise "under-banked" SMEs and households. It thus makes much sense to use the Brazilian banking market as a laboratory for our research question on whether CUs were able to provide insurance to their members during the financial crisis of 2008/09.

\section{Data and Descriptive Statistics}

For our empirical analysis, we use three datasets obtained from the BCB: first, credit register loan-level data on lending from Brazilian banks to Brazilian firms; second, bank-level data on Brazilian banks' balance sheet information; and third, firm-level data on Brazilian firms from RAIS.

\section{A. Triplet Data}

To investigate the lending behavior of CUs versus non-CUs, we use triplet data on the firmbank-time dimensions. The data on bank-firm credit relationships are reported by the financial institutions to the credit registry of the $\mathrm{BCB}$. The credit register lists all outstanding loan amounts above a threshold of 5,000 Brazilian Real $(\mathrm{BRL})^{8}$ that each borrower has with financial institutions operating in Brazil, including government banks, private domestic banks, foreign banks, and CUs. Data are reported at a monthly frequency. The intermediaries use the credit registry as a screening and monitoring device for borrowers. It is also employed by the BCB to monitor and supervise the banking sector 9 .

\footnotetext{
${ }^{8}$ Approximately 2,600 USD on average for the period of analysis.

${ }^{9}$ The Central Bank ensures the quality of the data. For example, the total outstanding loan amount at the credit registry must match the accounting figures for credit for any individual bank.
} 
For bank-level variables, we obtained consolidated and unconsolidated balance sheet data from the BCB. The data are with quarterly frequency for all the banks and CUs operating in Brazil. Additionally, we have bank ownership and conglomerate information. We merge these different datasets using the public bank identification number. For the purpose of our analysis, we focus on information around the GFC, more precisely, after Lehman Brothers' collapse in September 2008. We argue that the GFC represents a negative shock to the growing Brazilian credit market. Therefore, the quarter in which we split the sample is 2008:Q3. The Crisis dummy equals 1 from 2008:Q3 to 2010:Q2. If the insurance effect is dominating the equity effect, we expect that CUs will be less respondent to the crisis in comparison with non-CUs.

We select a sample period that runs from 2006:Q3 until 2010:Q2. This is a four-year sample, two years before and two years after the shock. A pre-crisis period of at most two years has the advantage of reducing the risk that the results are influenced by other events or developments occurring in the previous period. We choose 2010:Q2 as the end of the sample period (two years after the shock) to avoid contamination of our results by the effects of the European Sovereign Crisis, which worsened along 2010. ${ }^{10}$

The impact of the GFC on bank lending in Brazil is illustrated in Figure 1. It shows the growth of loans for CUs and non-CUs in the pre-crisis and the crisis periods, relative to the quarter of the shock, i.e., 2008:Q3. In the pre-crisis period, the average growth rate of loans for CUs was $9.2 \%$, whereas for non-CUs, it was $6.8 \%$. The average growth rate reduced for both groups after the shock, showing the average growth rate of $6.8 \%$ for CUs and $5.1 \%$ for non-CUs. This implies that the growth rate reduced by 2.4 percentage points for CUs compared with the drop of 1.7

\footnotetext{
${ }^{10}$ As a robustness check, we do the exercise using the period from 2007:Q3 to 2009:Q2 (1 year before and 1 year after the shock). Results are qualitatively unchanged and are available from the authors upon request.
} 
percentage points for non-CUs. Overall, the data indicate that the crisis reduced the growth of bank lending in Brazil.

The samples we use from the credit registry include all non-financial and private firms with outstanding credit. Following the literature, we exclude default operations with more than 90 days, reducing the risk that results are influenced by the carrying amount of non-paid debt in the dependent variable. The results are robust to the inclusion of default loans. ${ }^{11}$ The sample of banks includes CUs and non-CUs with a commercial portfolio. The data level is a triplet on the firmbank-quarter dimensions.

Table 1 shows the definitions of all variables used in our paper. The primary dependent variable is Amount, defined as the natural logarithm of the total outstanding loan amount of borrower $i$ at bank $b$ in quarter $t$. We additionally analyze the effect of the crisis on Maturity, Interest, Collateral, Risk, and Future default to understand the multitude of possible effects on the credit relationship of firms with CUs and non-CUs in Brazil.

We use a dummy variable to indicate bank type. $C U$ takes the value one if the financial institution is a CU. Additionally, we have several time-variant bank-level characteristics, which include the size of the bank, the ratio of liquid assets, fixed assets, deposits, equity, non-performing loans to total assets, and return on equity. These controls check the robustness of our findings, i.e., whether the inclusion of other covariates changes the results estimated in the baseline models.

To control for credit demand and other kinds of unobservable firm heterogeneity, we select only firms borrowing from at least two banks in the same quarter. As the identification strategy

\footnotetext{
${ }^{11}$ In the case that a firm is in default for more than 90 days and continues in this situation, the outstanding loan amount stays the same throughout the sample period. By excluding these operations, we are able to follow the actual change in the credit supply of banks in the post-period.
} 
relies on a comparison between the behavior of CUs and non-CUs at the same time, we select firms that borrow from at least one $\mathrm{CU}$ and one non-CU (foreign, private, domestic, or government-owned bank) in the pre-crisis and in the crisis periods. ${ }^{12}$

In other words, we apply (i) a cross-section filter, where firms must have a relationship with a $\mathrm{CU}$ and a non-CU in the same quarter, and (ii) a time-series filter, where firm-bank relationships must appear before and after the shock. Specifically, we investigate the impact on the intensive margin of the same firm at the same point in time for CUs and non-CUs to disentangle bank's credit supply from the firm's credit demand.

We recognize that the restricted sample may not be representative of the population of the firms in Brazil. However, this selection bias may be beneficial for our analysis. The non-exclusive banking relationships, i.e., relationships with multiple banks at the same time, show that these firms may have a better chance of accessing credit (if not from one bank, from another one). Our sample lets us study the firms that were not credit-constrained before the crisis. This is precisely what we want to capture in terms of credit supply and additional credit features.

Table 2 shows summary statistics of all variables from our triplet data sample. We track 43,852 firms and 1,001 banks (812 CUs and 189 non-CUs) that together result in 191,829 firmbank pairs in a total of $1,446,903$ observations. The median loan amount is approximately 34,800 BRL, with a median remaining maturity of over seven months, a median annual interest rate of approximately $20 \%$ and collateral rate of around $34 \% .{ }^{13}$ On average, the future default with a oneyear horizon, i.e., default on a loan within four quarters, is approximately $2 \%$. Firms have a median of three loans with a bank and a median of three active banking relationships, where the average

\footnotetext{
${ }^{12}$ As a robustness check, we exclude the public banks from the sample (22 banks). Results for both loan market and labor market are qualitatively unchanged and are available from the authors upon request.

${ }^{13}$ Median loan amount in USD is 18,000 on average for the period of analysis.
} 
market share is $31 \%$. The median banking relationship duration is slightly below 3.5 years, and the median firm's age is approximately ten years.

CUs correspond to $34 \%$ of the observations of bank-firm relationships, and $56 \%$ of the observations are in the crisis period. The bank asset size in the sample is approximately 9.5 billion BRL on average, with a balance sheet structure of $28 \%$ of their total assets invested in liquid assets and $7 \%$ in fixed assets. ${ }^{14}$ On average, non-performing loans represent $3 \%$. The median bank has $59 \%$ of its obligations as deposits and $13 \%$ as equity. The median bank has a net positive annual return on assets. However, there is extreme variance in the cross-section dimension of banks' balance sheet structure and size. Because such differences can be correlated with credit supply, we include bank fixed effects and time-variant bank characteristics in our specifications.

\section{B. Firm-level Data}

To study the labor market effects of the CUs' insurance effect, we use the RAIS data. RAIS is the database of the labor market that is collected annually by the Ministry of Economy (ME). RAIS contains information on the characteristics of the firms and their formal workers on an individual level. The data cover various characteristics of firms and employees such as demographics, occupation, industry, income, job starting dates, and termination dates. Firms are required by law to provide detailed information about their employees to the ME.

To prepare our sample, first we aggregate the firm-bank-time level credit registry data to the firm-time level. Then, we merge the RAIS data with the credit registry data using the unique firm ID. The resulting data are at the firm-quarter level. Our sample period for labor market analysis runs from 2007:Q3 until 2010:Q2. This is a three-year sample, one year before and two

\footnotetext{
${ }^{14}$ Bank size of approximately 5 billion USD on average for the period of analysis. The bank size in Table 2 is $\log$ of total assets of the bank.
} 
years after the shock. We cover a shorter period because the RAIS data starts in 2007. We use the variables Employment and Wages, where Employment represents the log of number of employees and Wages is the log of average wages in Brazilian Real (BRL).

In order to achieve a homogeneous sample of SME firms, we exclude 325 large firms from the sample. SMEs are most relevant to our context because the CUs are an important source of finance mainly for small businesses. We follow Chodorow-Reich (2014) and study employment effects by firm size. To categorize the firms by size, we use the OECD's classification of SMEs. Microenterprises are firms that employ fewer than 10 employees, small firms employ from 10 to 49 employees, and medium firms employ from 50 to 249 employees. Our final merged sample has 12,694 firms and 439,211 observations.

Panel A of Table 7 shows summary statistics for our sample of SMEs from RAIS data. It shows that, on average, the SMEs have 30 employees. The median number of employees is 13 , and the standard deviation is 43 . The average annual wage paid by the firms is $R \$ 26,363$; median wage is $R \$ 9,148$, and the standard deviation is $R \$ 45,783$.

\section{Empirical Strategy}

\section{A. Loan Market}

We use the following specification to investigate whether CUs differ with respect to lending volume during the GFC compared to other banks. We start with a specification without any fixed effects and covariates:

$$
Y_{i b t}=\alpha+C U_{b}+\text { Crisis }_{t}+\beta C U_{b}{ }^{*} \text { Crisis }_{t}+\varepsilon_{i b t},
$$

where $Y$ represents our measures of the intensive margin, which include Amount, Maturity, Interest 
or Collateral, a risk measure Risk, and measures of loan performance, i.e., Future default 1 yr, Future default 2 yr and Future default 3 yr. In particular, Amount equals the total outstanding credit volume of bank $b$ towards firm $i$ in quarter $t$. $C U$ takes the value 1 if bank $b$ is a credit union and 0 otherwise; Crisis equals 1 from 2008:Q3 to 2010:Q2 and 0 otherwise. Overall, we expect a negative effect of the crisis on existing firm-bank relationships, for instance, a decrease in the outstanding loan amount, which may be driven by both credit supply and demand. Financial crisis is a bank-level liquidity shock. Thus, changes in the loan from the same bank can be correlated. Therefore, we cluster all errors at the bank level.

The main identification challenge is the simultaneous nature of credit supply and credit demand. We aim to capture demand shocks at the firm level by using firm-time fixed effects, $\alpha_{i t}$, i.e., in the sense that we investigate the same firm at the same point in time. This approach comes at the cost that we will need to constrain our analysis to those firms with multiple bank relationships at the same time. Our most saturated specification is thus:

$$
Y_{i b t}=\alpha_{i t}+\alpha_{i b}+\beta C U_{b} * \text { Crisis }_{t}+X_{b t}+\varepsilon_{i b t}
$$

where the second set of fixed effects, $\alpha_{i b}$, controls for unobserved cross-sectional heterogeneity at the firm-bank pair level. This also includes time-invariant heterogeneity of credit supply at this level. Vector X controls for a set of time-variant observable characteristics of bank $b$ at time $t$ such as the size of the bank, the ratio of liquid assets, fixed assets, deposits, capital, non-performing loans to total assets, and return on equity. These bank characteristics are used to control for further time-variant bank-specific determinants of credit supply.

The coefficient of interest in the specification (2), $\beta$, is the interaction of $C U$ with $C r i s i s$. We want to concentrate on the financial crisis because this was a period when insurance against credit constraints was most important to firms. If the coefficient of interest turns out to be positive, 
CUs would have decreased the loan amounts to the same firm at the same point in time to a lesser extent than other types of lenders. This case would lend support to the insurance effect. On the contrary, if the coefficient is negative, CUs would have reduced the loan amounts to a larger extent than other types of lenders. This would be evidence for the equity effect. CU members can leave the union anytime, which would reduce the equity of the CU. As the risk of insolvency increases during times of financial distress, members may indeed withdraw their equity during the crisis. The coefficient of interest would show whether CUs behave differently with respect to their equity ratio than other lenders.

We further test whether results depend on the banks' equity ratio. Banks with a high equity ratio may have been able to maintain lending to their commercial clients, while those with low equity ratios may have been less able to do so. We thus define a new dummy variable, HighEquity, which equals one for CUs (non-CUs) if a CU's (non-CUs) equity is above the median for all CUs (non-CUs) in quarter $t$. Note that the equity ratio was included in vector $\mathrm{X}$ in specifications (1) and (2):

$$
\begin{gathered}
Y_{i b t}=\alpha_{i t}+\alpha_{i b}+\beta_{1} \text { HighEquity }_{b t}+\beta_{2} C U_{b} * \text { Crisis }_{t}+\beta_{3} \text { HighEquity }_{b t} * \text { Crisis }_{t}+ \\
\beta_{4} C U_{b} * \text { HighEquity }_{b t}+\beta_{5} C U_{b} * \text { Crisis }_{t} * \text { HighEquity }_{b t}+X_{b t}+\varepsilon_{i b t},
\end{gathered}
$$

in which $\beta_{5}$ is the main coefficient of interest. We include firm-time and firm-bank fixed effects in specification (3).

\section{B. Labor Market}

We extend our analysis by studying the labor market effects of the CUs' behavior of providing insurance to their members. We test whether the firms that had a higher share of lending from the CUs before the crisis were able to maintain (or increase) employment during the crisis period. We 
thus generate a new dummy variable, HighShare, which equals one if firms had a high share of loans (above median) from the CUs before the crisis and zero otherwise (LowShare). We use the following specification:

$$
Y_{i t}=\alpha_{i}+\alpha_{t}+\beta \text { HighShare }_{i}{ }^{*} \text { Crisis }_{t}+\varepsilon_{i t},
$$

where $Y_{i t}$ represents the dependent variables Employment and Wages at the firm-time level. The firm and time fixed effects are captured by $\alpha_{i}$ and $\alpha_{t}$, respectively. The errors, $\varepsilon_{i t}$, are clustered at the firm level. Specification (4) is different from specifications (1) to (3) because here we are interested in the firm-level outcomes for which the setup is two-dimensional, i.e., firm-time level.

\section{Loan Market Results}

\section{A. Univariate Analysis}

Table 3 introduces our univariate difference-in-difference (DD) analysis using specification (1). We test the difference of means between the CUs and the non-CUs for our dependent variables in the pre-crisis and the crisis periods. To do so, we aggregate the data on a single data point (based on averages) for each of the groups of interest and compute differences. We have 211,662 observations for CUs in the pre-crisis period and 275,191 in the crisis period, whereas for non-CUs, there are 426,839 observations in the pre-crisis period and 533,211 in the crisis period.

For the first difference, we observe that the direction of difference for all variables is the same for the CUs and the non-CUs except for the interest rate. On average, the firms have lower outstanding loan amount with the CUs than with the non-CUs in both the pre-crisis and the crisis periods. However, there is an increase in the average outstanding loan amount for both groups during the crisis period, with the increase being higher for the CUs. The change in the average 
outstanding loan amount for the CUs is approximately 0.069 compared to the change of 0.015 for the non-CUs. This is also reflected in column (7) of Table 3. The double difference of 0.054 indicates that the CUs increased credit supply more than the non-CUs in the crisis period. It is worthwhile noting hat both CUs and non-CUs slightly increased the average loan amount. However, this has to be interpreted in light of the still growing market for bank loans, even though the growth rates of the total loan amount decreased during the crisis by approximately two percentage points (see Figure 1). The growth of the average loan amount also supports this finding: CUs were increasing the average loan amount by $0.9 \%$ on a quarterly basis in the pre-crisis period, while this growth rose to $2 \%$ during the crisis. In contrast, the quarterly growth rate of the average loan amount decreased from $3.2 \%$ during the pre-crisis period to $2.2 \%$ during the crisis period in the case of non-CUs.

One can observe that the loans from the CUs have on average six months shorter remaining maturity in the pre-crisis period compared to the non-CUs $(-0.481 * 365)$. However, the difference reduced in the crisis period, indicating that the remaining maturity of loans from the CUs increased more in the crisis period compared to the non-CUs. This is also evident from the double difference of 0.132 in column (7), which implies that, in the crisis period, maturity of the credit provided by CUs increased by 48 days $(0.132 * 365)$ compared to non-CUs. Additionally, the CUs increased the interest rate during the crisis, while the non-CUs decreased the interest rate. On average, the CUs charged a slightly higher interest rate than the non-CUs before the shock, while after the shock, they charged considerably higher interest rates than non-CUs. The double difference indicates that the CUs charged on average 2.673 percentage points more interest than the non-CUs in the crisis period. The CUs required on average less collateral than the non-CUs in the pre-crisis period. In the crisis period, even though both CUs and non-CUs required more collateral, the double 
difference of -0.054 shows that the collateral requirement increased more for the non-CUs than for the CUs.

The loans of the CUs carried lower risk in the pre-crisis period compared to the non-CUs. The risk increased for both groups after the shock, with the increase being greater in the case of the non-CUs' loans. The future default rate in the first, second, and third years is lower for the CUs than for the non-CUs both in the pre-crisis and the crisis periods. It is interesting to note that the future default rate (in years one, two, and three) decreased after the shock for both bank groups. This outcome should be studied in combination with the change in the amount of lending. The CUs increased credit supply more than the non-CUs in the crisis period. However, the double differences of all three future default measures show that there was almost no difference in the future default rate of loans of CUs and non-CUs. The only exception is the second year, where the decrease in future default rate was slightly lower for the CUs in the crisis period.

Thus, the double differences indicate that, in the crisis period, the CUs supplied larger loans, of longer maturity, and with lower collateral requirements but without any noticeable adverse impact on the performance of the loans. Overall, the evidence so far seems to support the insurance effect of CUs, meaning that the CUs provided insurance to their members against credit constraints in dire times.

\section{B. Intensive Margin}

Table 4 provides the first regression results. We regress Amount, Maturity, Interest, and Collateral on $C U$ in the crisis period in a differences-in-differences approach. Columns (1) to (3) show the effect of the dummy $C U$ on the amount of credit supplied in the period from 2008:Q3 to 2010:Q2. In column (1), we include bank fixed effects to control for any time-invariant bank 
characteristics. The estimate of coefficient $\beta$ is not statistically significant, although it is positive and economically meaningful. To address the possibility of time-varying differences in borrower demand, we include firm-time fixed effects in column (2). In this setting, the coefficient of the interaction term becomes statistically significant at the $10 \%$ level, with an approximate $9 \%$ increase in credit supply. The last specification of column (3) is our preferred one because it takes into account the demand effects and unobserved firm-bank heterogeneity. The point estimate for $\beta$ increases to $17.2 \%$ and is statistically significant at the $1 \%$ level once we further include timevarying bank characteristics and add firm-bank fixed effects instead of bank fixed effects. This implies that, during the crisis, CUs increased credit supply by 17.2 percentage points compared with non-CUs. This result accounts for $77.67 \%$ of unconditional standard deviation (Table 2), which indicates its economic significance. This result is particularly interesting because we know that the Brazilian public banks also displayed non-cyclical behavior during the GFC (IMF, 2012). Hence, we document CUs as private mechanisms/institutions to offset the effects of the GFC.

In columns (4) to (6), the outcome variable is Maturity. In column (4), the estimate of coefficient $\beta$ is not statistically significant but one can observe that the Maturity of loans from CUs increased more during the crisis than that of the loans from non-CUs. In Column (5), with bank fixed effects and firm-time fixed effects, the estimate of coefficient $\beta$ is significant at the $10 \%$ level. It shows that, in the crisis period, Maturity of the credit provided by CUs increased by 1.2 months when compared with non-CUs. Column (6) presents the preferred estimation. CUs increased the remaining maturity by 2.7 months compared with non-CUs. The inclusion of a set of fixed effects and time-varying bank controls in the specification (6) makes it unlikely that the results are driven by unobservable time-varying differences in borrower demand and quality, by 
time-invariant bank heterogeneity, or by time-varying differences in the bank's structure, behavior, or risk appetite.

In columns (7) to (9), we document the effects of the financial crisis on Interest. It can be observed throughout the specifications that, in the crisis period, CUs charged higher interest rates than non-CUs to provide credit to firms. Using our most saturated specification, we find that CUs charged an additional interest rate of 1.7 percentage point. This is an economically and statistically significant finding. However, this effect needs to be seen in perspective with Brazilian basic interest rates, which were approximately $10 \%$ for the crisis period. Furthermore, the results for the interest rate need to be considered together with the collateral requirement, the results for which are displayed in columns (10) to (12). Throughout the specifications, we find that CUs required on average $6 \%$ less collateral in the crisis period when compared to non-CUs. These results might corroborate the thesis that CUs would be more inclined to take risks in a period of distress for the banking sector in Brazil.

\section{Risk and Loan Performance}

To study whether the behavior of CUs (i.e., supplying more credit, with longer maturities, higher interest rates, and less collateral) was translated into higher risk-taking, we test whether Risk and Future default changed in the crisis period for CUs versus non-CUs. First, we check whether the overall risk of the portfolio changed over time. In columns (1) to (3) of Table 5, we use Risk, defined as the weighted average risk from zero (no risk) to one (100\% risk) of borrower $i$ at bank $b$ in quarter $t$. This variable is the same as that used by the BCB to monitor the provision levels of credit portfolios of banks. ${ }^{15}$ It has the advantage that it allows us to take into account the

${ }^{15} \mathrm{BCB}$ requires the banks to classify their credit portfolios in nine rating levels ranging from "AA", "A" to "H". Rating "AA" represents the best rating a loan can achieve (lowest credit risk) and " $\mathrm{H}$ " represents the worst rating a 
changes in risk levels of loans that are both below and above 90 days overdue. This detailed tracking of Risk might not be possible if we consider only the defaulted loans above 90 days. Throughout the specifications, we find that CUs did not display higher risk on their credit portfolios when compared to non-CUs in the crisis period.

At this stage, one may argue that just the fact that CUs supplied more credit could explain the lower rates of risk because new credit rises normally with higher ratings. Therefore, we also test the performance of a loan in the next one to three years using Future default 1 yr, Future default $2 y r$, and Future default $3 y r$ as dependent variables. Future default 1 yr is defined as a dummy variable that takes the value one in the presence of a defaulted loan for borrower $i$ at bank $b$ in quarter $t+4$. Similarly, Future default $2 y r$ and Future default $3 y r$ take the value one in the presence of a defaulted loan for borrower $i$ at bank $b$ in quarters $t+8$ and $t+12$, respectively. The results are shown in Table 5. Throughout columns (4) to (12), we find positive results in the direction that CUs presented higher rates of future default in the crisis period when compared to non-CUs. The results for our most saturated specification are statistically significant. In the crisis period, the future default rate of loans of CUs within one year is $0.6 \%$ higher compared to nonCUs. The future default rate is $1.4 \%$ higher than non-CUs in the second year and $0.7 \%$ higher than non-CUs in the third year. It makes sense to read these findings together with the result of Risk. Although the risk at the time of loan approval was not perceived to be higher than that of nonCUs, the increased supply of credit at higher interest rates resulted in higher default rates ex post.

Nonetheless, the results of Table 4 and 5 present evidence of the importance of CUs in offsetting the effect of the financial crisis of 2008. These institutions provided more credit, with

\footnotetext{
loan can be assigned (highest credit risk). Each rating level is associated with a percentage provision of the total due amount of the loan, e.g., rating " $A$ " corresponds to $0.5 \%$ provision of total due amount. We assign numerical values to the rating of each loan of firm $i$ at bank $b$ in quarter $t$ and compute the weighted average Risk.
} 
longer maturities, higher interest rates, and less collateral in the crisis period when compared to non-CUs. However, this behavior was translated into higher credit risk ex post.

\section{Heterogeneous Effects}

Table 6 presents the results of our specification (3), i.e., the heterogeneous effects of the equity ratio. Columns (1) to (8), respectively, report the effect on Amount, Maturity, Interest, Collateral, Risk, Future default 1 yr, Future default $2 y r$, and Future default $3 y r$ of the loans granted by banks with high equity ratio in the period from 2008:Q3 to 2010:Q2. Column (1) shows that the coefficient of interest for Amount is statistically significant and increases to 0.23 . This finding suggests that CUs with equity ratio above the median provided on average $23 \%$ more loans during the crisis period compared to non-CUs. This also implies that most likely because of the lack of capital, CUs with equity ratio below the median were not able to supply more loans in the crisis period, i.e., were not able to provide insurance to their members.

Results in column (2), although not statistically significant, show that HighEquity CUs provided loans of greater maturity compared to non-CUs during the crisis. Moving to column (3), we find that the interest rate charged by HighEquity CUs increased during the crisis. The CUs with equity ratio above median charged on average $2.4 \%$ higher interest rate than non-CUs. In columns (4) to (7), we do not generally observe any significant impact on the coefficients of interest. In column (8), we have a statistically significant finding at the $10 \%$ level, indicating that in the next three years, CUs with above median equity ratio faced $0.5 \%$ fewer defaults than non-CUs. Overall, 
the findings of specification (3) support the insurance effect observed in our specification (2). We thus conclude that the insurance effect seems to dominate the equity effect. ${ }^{16}$

\section{Labor Market Effects}

We next investigate whether the insurance effect has an impact on labor market outcomes. We first have a look at the univariate DD estimates. Panel (b) of Table 7 reports the DD estimates for all firms together, and separately for micro, small and medium firms. The overall results of this stage of the analysis suggest that the active insurance effect of the CUs translated into positive labor market effect. In terms of differences between firms that had a higher share of loans from CUs before the crisis (HighShare) and the firms that had a lower share of loans from CUs before the crisis (LowShare) statistics show that medium-sized HighShare firms increased their employment and wages after crisis more than their LowShare counterparts. Also, small HighShare firms increased their employment more than small LowShare firms. However, the double differences which are the differences between changes in wage and employment of HighShare and LowShare firms are not very inclusive in this stage. In the next level of estimations, we provide more in-depth analysis by controlling for certain characteristics and fixed effects.

Table 8 presents the fixed effects regression results for Employment. Columns (1) to (3) report the effect of the dummy HighShare on Employment level of the micro firms in the crisis period. ${ }^{17}$ Columns (4) to (6) report the same for the small firms, and columns (7) to (9) show the results for the medium firms. In column (3), which is our most saturated specification for micro

\footnotetext{
${ }^{16}$ Our loan market results remain qualitatively unchanged if we divide the firms by size into micro, small, and medium firms.

${ }^{17}$ As an alternative to dummy HighShare, we estimated our labor market results using share of CUs as a continuous variable that takes value between 0 and 1 . The results are qualitatively unchanged and available from the authors upon request.
} 
firms, the coefficient of interest for Employment is statistically significant at the $1 \%$ level. The positive value of 0.023 shows that the micro firms that had above-median loans from the CUs in the pre-crisis period were able to increase employment on average by 0.023 percentage point during the crisis period. For the small firms, the positive point estimate for $\beta$ in column (6), although not significant, indicates positive employment outcomes. For the medium firms, the coefficient in column (7) indicates positive effects on employment, although not significant. However, the coefficient turns negative when we include firm fixed effects in column (8) and both firm and time fixed effects in column (9).

Table 9 reports the effect of the dummy HighShare on Wages paid by the firms in the crisis period using fixed effects regressions. As in Table (8), columns (1) to (3) report the results for micro firms, columns (4) to (6) for the small firms, and columns (7) to (9) for the medium firms. For micro firms, column (3) reports statistically significant results at the 5\% level. The estimate for $\beta$ shows that the micro firms that had above-median loans from the CUs before the crisis paid on average 3\% higher wages during the crisis period. For small and medium firms, the estimates for $\beta$ are not significant throughout columns (4) to (9). The effect on wages paid by the small firms is overall negative. For the medium firms, column (7) shows a positive estimate of 0.016 . Our most saturated specification in columns (6) and (9), for small and medium firms respectively report slightly negative estimates for $\beta .^{18}$

The higher dependence of micro and small firms on CUs is also evident from the number

\footnotetext{
${ }^{18}$ i) We estimated our labor market regressions by grouping firms into micro, small, and medium firms according to the criteria in the Brazilian Corporate Law. This classification is based on revenues of firms instead of number of employees. Our labor market results are qualitatively unchanged and available from the authors upon request.

ii) We estimated our labor market results using another sample of RAIS data that also includes firms with 0 employees (self-employed). These data are annual and not well-suited for our research design. Nonetheless, our labor market results remain qualitatively unchanged and are available from the authors upon request.
} 
of observations for each group of firms in Tables 8 and 9. In our sample of firms that borrow from both the CUs and the non-CUs, micro firms make the biggest proportion of observations, i.e., 63,095 , whereas the number of observations for the medium firms is roughly only $25 \%$ of the micro firms. Thus, the findings of our paper suggest that the CUs support their members by easing credit constraints during dire times. Further, the active insurance effect of the CUs translates into positive effects on the real economy in the form of an increase in employment and wages among micro firms.

\section{Conclusions}

In this paper, we analyze the lending behavior of CUs as prototypical relationship lenders and the subsequent effects on the borrowing firms' labor force during the GFC. Our results imply that, during the crisis, Brazilian CUs tighten credit to borrowers less than other bank types (insurance effect). This outcome is consistent with the insurance hypothesis that CUs, compared to other banks, try harder to support their borrowers during dire times. CU members enjoyed longer maturity loans and less collateral requirement. However, CU members were paying higher interest rates for this type of insurance, and CUs faced higher future default frequencies. We further provide empirical evidence on the labor market outcome of the CUs' insurance effect, which transmitted to more employment and higher wages for very small firms. Overall, CUs appear to be able to mitigate the propagation of negative shocks of the GFC because of their non-procyclical behavior during the crisis. 


\section{References}

Albertazzi, Ugo, and Domenico Junior Marchetti. "Credit Supply, Flight to Quality and Evergreening: An Analysis of Bank-firm Relationships after Lehman." Working Paper No. 756. Bank of Italy, 2010.

Angelini, Paolo, Roberto Di Salvo, and Giovanni Ferri. "Availability and Cost of Credit for Small Businesses: Customer Relationships and Credit Cooperatives.” Journal of Banking \& Finance 22 (1998): 925-954.

Bayoumi, Tamim, and Gabrielle Lipworth. "Japanese Foreign Direct Investment and Regional Trade." Journal of Asian Economics 9 (1999): 581-607.

Benmelech, Efraim, Nittai K. Bergman, and Amit Seru. Financing Labor. Working Paper No. w17144. National Bureau of Economic Research, 2011.

Berlin, Mitchell, and Loretta J. Mester. "On the Profitability and Cost of Relationship Lending." Journal of Banking \& Finance 22 (1998): 873-897.

Chava, Sudheer, and Amiyatosh Purnanandam. "The Effect of Banking Crisis on Bank-dependent Borrowers." Journal of Financial Economics 99 (2011): 116-135.

Chodorow-Reich, Gabriel. "The Employment Effects of Credit Market Disruptions: Firm-level Evidence from the 2008-9 Financial Crisis.” Quarterly Journal of Economics 129 (2014): 1-59.

Cole, Rebel A. "The Importance of Relationships to the Availability of Credit." Journal of Banking \& Finance 22 (1998): 959-977. 
Coleman, Nicholas, and Leo Feler. "Bank Ownership, Lending, and Local Economic Performance during the 2008-2009 Financial Crisis." Journal of Monetary Economics 71 (2015): 50-66.

Elsas, Ralf, and Jan Pieter Krahnen. "Is Relationship Lending Special? Evidence from Credit-file Data in Germany." Journal of Banking \& Finance 22 (1998): 1283-1316.

Ferri, Giovanni, and Marcello Messori. "Bank-firm Relationships and Allocative Efficiency in Northeastern and Central Italy and in the South." Journal of Banking \& Finance 24 (2000): 10671095.

Hackethal, Andreas. "German Banks and Banking Structure". Working Paper No. 106. Department of Finance, Goethe University Frankfurt am Main, 2004.

Hoshi, Takeo, Anil Kashyap, and David Scharfstein. "The Role of Banks in Reducing the Costs of Financial Distress in Japan.” Journal of Financial Economics 27 (1990): 67-88.

Iyer, Rajkamal, José-Luis Peydró, Samuel da-Rocha-Lopes, and Antoinette Schoar. "Interbank Liquidity Crunch and the Firm Credit Crunch: Evidence from the 2007-2009 Crisis." Review of Financial Studies 27, No. 1 (2013): 347-372.

Jiménez, Gabriel, and Steven Ongena. "Credit Supply and Monetary Policy: Identifying the Bank Balance-sheet Channel with Loan Applications." American Economic Review 102 (2012): 23012326.

Jiménez, Gabriel, Steven Ongena, José-Luis Peydró, and Jesús Saurina. "Hazardous Times for Monetary Policy: What Do Twenty-Three Million Bank Loans Say About the Effects of Monetary Policy on Credit Risk-Taking?" Econometrica 82 (2014): 463-505. 
Khwaja, Asim Ijaz, and Atif Mian. "Tracing the Impact of Bank Liquidity Shocks: Evidence from an Emerging Market.” American Economic Review 98 (2008): 1413-1442.

Machauer, Achim, and Martin Weber. "Number of Bank Relationships: An Indicator of Competition, Borrower Quality, or just Size?” Working Paper No. 2000/06. Goethe-Universität Center for Financial Studies, 2000.

Mian, Atif. "Distance Constraints: The Limits of Foreign Lending in Poor Economies." Journal of Finance 61 (2006): 1465-1505.

Morck, Randall, Masao Nakamura, and Murray Frank. "Japanese Corporate Governance and Macroeconomic Problems." In The Japanese Business and Economic System, 325-363. Palgrave Macmillan UK, 2001.

Paravisini, Daniel. "Local Bank Financial Constraints and Firm Access to External Finance." Journal of Finance 63 (2008): 2161-2193.

Peek, Joe, and Eric S. Rosengren. "The International Transmission of Financial Shocks: The Case of Japan." American Economic Review 87 (1997): 495-505.

Petersen, Mitchell A., and Raghuram G. Rajan. "The Benefits of Lending Relationships: Evidence from Small Business Data." Journal of Finance 49 (1994): 3-37.

Schnabl, Philipp. "The International Transmission of Bank Liquidity Shocks: Evidence from an Emerging Market.” Journal of Finance 67 (2012): 897-932.

Wagner, Wolf. "Systemic Liquidation Risk and the Diversity-Diversification Trade-Off." Journal of Finance 66 (2011): 1141-1175. 
Figure 1

Growth of Total Loan Volume

This figure illustrates the growth of total loan volume for firms borrowing from CUs and non-CUs in the pre-crisis and the crisis periods. The data span the quarters of 2006:Q3 to 2010:Q2 where the pre-crisis period ranges from 2006:Q3 to 2008:Q2 and the crisis period is from 2008:Q3 to 2010:Q2. The loans (log of the outstanding loan amount) are aggregated for each quarter for CUs and non-CUs. The loans from both CUs and non-CUs are forced to be zero at the start of our crisis period, i.e., 2008:Q3. Thus, the time series shows the growth rate of loans relative to the quarter of the shock.

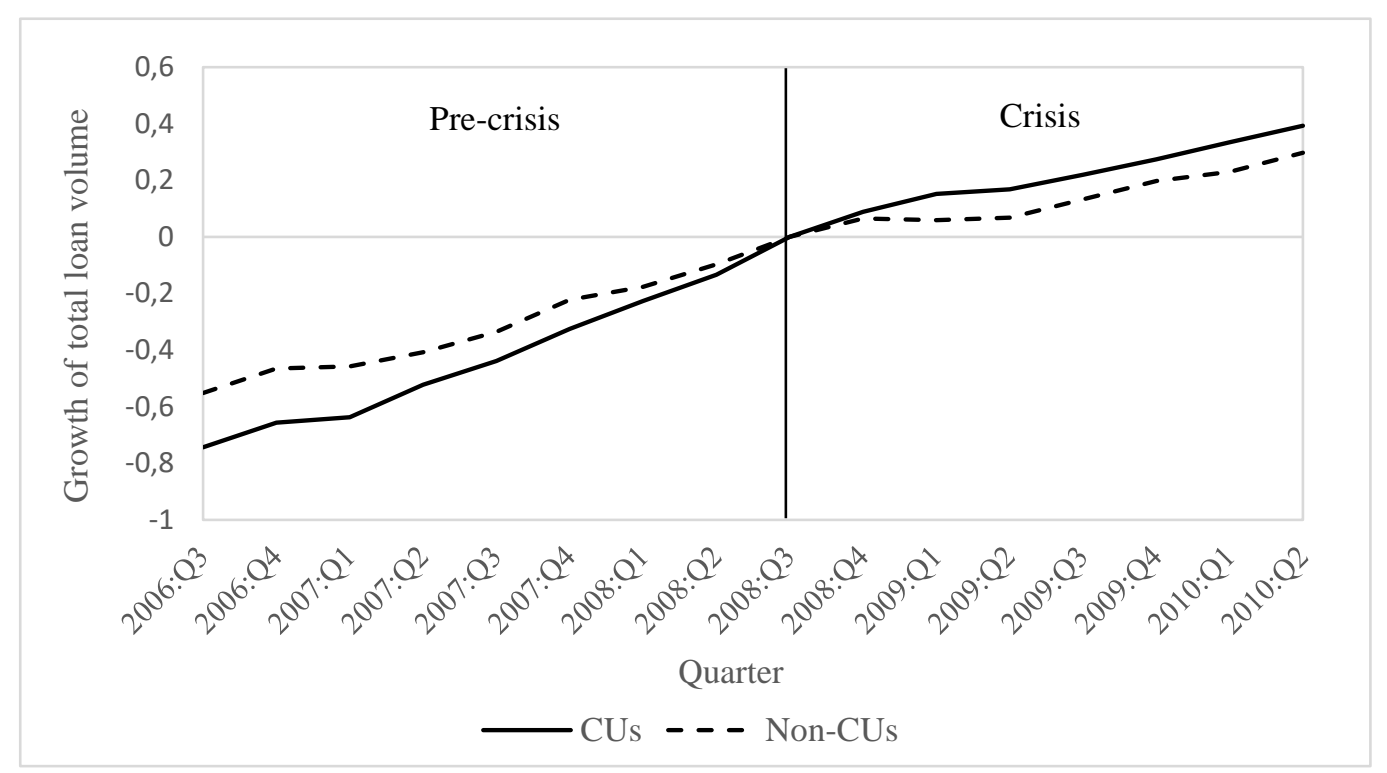




\section{Table 1 \\ Variables Definitions}

The table presents the definitions of variables used in the paper. We use credit registry data, bank ownership data, quarterly accounting information, and RAIS data provided by the Central Bank of Brazil.

\begin{tabular}{|c|c|}
\hline Variable name & Definition \\
\hline Amount & Log of outstanding loan amount of borrower $i$ at bank $b$ in quarter $t$ \\
\hline Amount in BRL & Outstanding loan amount in Brazilian Real of borrower $i$ at bank $b$ in quarter $t$ \\
\hline Maturity & Remaining loan maturity in years of borrower $i$ at bank $b$ in quarter $t$ \\
\hline Interest & Weighted annual loan interest rate of borrower $i$ at bank $b$ in quarter $t$ \\
\hline Collateral & Weighted average ratio of collateral from zero to one of borrower $i$ at bank $b$ in quarter $t$ \\
\hline Risk & Weighted average risk from zero (no risk) to one (100\% risk) of borrower $i$ at bank $b$ in quarter $t$ \\
\hline Future default $1 \mathrm{yr}$ & $\begin{array}{l}\text { Dummy variable that takes the value one in the presence of a defaulted loan for borrower } i \text { at bank } b \\
\text { in quarter } t+4\end{array}$ \\
\hline Future default $2 \mathrm{yr}$ & $\begin{array}{l}\text { Dummy variable that takes the value one in the presence of a defaulted loan for borrower } i \text { at bank } b \\
\text { in quarter } t+8\end{array}$ \\
\hline Future default 3 yr & $\begin{array}{l}\text { Dummy variable that takes the value one in the presence of a defaulted loan for borrower } i \text { at bank } b \\
\text { in quarter } t+12\end{array}$ \\
\hline Employment & $\log$ of number of employees of firm $i$ in quarter $t$ \\
\hline Employees & Number of employees of firm $i$ in quarter $t$ \\
\hline Wage $(\log )$ & Log of average annual wage paid by firm $i$ in quarter $t$ \\
\hline Wage in BRL & Average annual wage in Brazilian Real paid by firm $i$ in quarter $t$ \\
\hline Loans & Number of loans of borrower $i$ at bank $b$ in quarter $t$ \\
\hline Relationships & Number of financial institutions with outstanding loan amount of borrower $i$ in quarter $t$ \\
\hline Market share & Market share of bank $b$ for the total credit of borrower $i$ in quarter $t$ \\
\hline Primary bank & Dummy variable that takes the value one for the bank with the larger Market share \\
\hline Relative duration & Relationship duration in years of borrower $i$ at bank $b$ \\
\hline Oldest bank & Dummy variable that takes the value one for the bank with the longest Relative duration \\
\hline Firm age & Age in years of borrower $i$ \\
\hline $\mathrm{CU}$ & Dummy variable that takes the value one for a $\mathrm{CU}$ \\
\hline Crisis & Dummy variable that takes the value one from 2008:Q3 to 2010:Q2 and zero otherwise \\
\hline Size & Log of total assets of the bank, adjusted by official inflation index, winsorized on $2 \% / 98 \%$ level \\
\hline Liquid assets & Ratio of liquid assets to total assets, winsorized on $1 \% / 99 \%$ level \\
\hline NPL & Ratio of non-performing loans to total assets, winsorized on $1 \% / 99 \%$ level \\
\hline Fixed assets & Ratio of fixed assets to total assets, winsorized on $1 \% / 99 \%$ level \\
\hline Deposits & Ratio of domestic deposits to total assets, winsorized on $1 \% / 99 \%$ level \\
\hline Equity & Ratio of equity to total assets, winsorized on $1 \% / 99 \%$ level \\
\hline ROE & Annual return on equity, winsorized on $1 \% / 99 \%$ level \\
\hline
\end{tabular}


Table 2

\section{Descriptive Statistics}

This table presents descriptive statistics of the variables used in the paper for our sample of firms. Our sample includes firms that borrow from at least one $\mathrm{CU}$ and from one non-CU (foreign, private domestic, or government-owned) in the pre-crisis and in the crisis periods. The data span the quarters of 2006:Q3 to 2010:Q2.

\begin{tabular}{|c|c|c|c|c|c|}
\hline Variable name & Mean & Sd. & Min & Median & $\operatorname{Max}$ \\
\hline Amount & 10.29 & 2.28 & 0.00 & 10.46 & 19.86 \\
\hline Amount in BRL (000) & 202.31 & $1,999.30$ & 0.00 & 34.80 & $422,000.00$ \\
\hline Maturity & 1.07 & 1.33 & 0.00 & 0.61 & 23.55 \\
\hline Interest rate & 25.36 & 27.77 & 0.00 & 20.00 & 100.00 \\
\hline Collateral & 0.43 & 0.43 & 0.00 & 0.34 & 1.00 \\
\hline Risk & 0.05 & 0.16 & 0.00 & 0.01 & 1.00 \\
\hline Future default $1 \mathrm{yr}$ & 0.02 & 0.13 & 0.00 & 0.00 & 1.00 \\
\hline Future default 2 yr & 0.06 & 0.24 & 0.00 & 0.00 & 1.00 \\
\hline Future default $3 \mathrm{yr}$ & 0.12 & 0.32 & 0.00 & 0.00 & 1.00 \\
\hline Loans & 4.58 & 6.26 & 1.00 & 3.00 & $1,616.00$ \\
\hline Relationships & 4.07 & 2.32 & 2.00 & 3.00 & 29.00 \\
\hline Market share & 0.31 & 0.27 & 0.00 & 0.24 & 1.00 \\
\hline Primary bank & 0.31 & 0.46 & 0.00 & 0.00 & 1.00 \\
\hline Relative duration & 5.24 & 5.57 & 0.00 & 3.38 & 42.38 \\
\hline Oldest bank & 0.33 & 0.47 & 0.00 & 0.00 & 1.00 \\
\hline Firm age & 13.63 & 10.01 & 0.08 & 10.97 & 75.57 \\
\hline $\mathrm{CU}$ & 0.34 & 0.47 & 0.00 & 0.00 & 1.00 \\
\hline Crisis & 0.56 & 0.50 & 0.00 & 1.00 & 1.00 \\
\hline Size & 23.00 & 3.92 & 10.86 & 24.82 & 27.03 \\
\hline Liquid assets & 0.28 & 0.12 & 0.00 & 0.27 & 1.00 \\
\hline NPL & 0.03 & 0.03 & 0.00 & 0.02 & 1.00 \\
\hline Fixed assets & 0.07 & 0.07 & 0.00 & 0.04 & 0.76 \\
\hline Deposits & 0.59 & 0.14 & 0.00 & 0.58 & 1.00 \\
\hline Equity & 0.13 & 0.09 & 0.00 & 0.10 & 1.00 \\
\hline ROE & 0.21 & 0.23 & -3.59 & 0.22 & 3.03 \\
\hline No. of observations & & & & & $1,446,903$ \\
\hline
\end{tabular}




\section{Table 3}

\section{Difference-in-Difference Analysis}

This table introduces our difference-in-difference (DD) analysis. We test the difference of means between CUs and non-CUs, before and during the crisis, for our sample of firms. Our sample includes firms that borrow from at least one CU and from one non-CU (foreign, private domestic, or government-owned) in the precrisis and in the crisis periods. We collapse the data into a single data point (based on averages) for each of the groups of interest and compute double differences. The data span the quarters of 2006:Q3 to 2010:Q2 where the pre-crisis period ranges from 2006:Q3 to 2008:Q2 and the crisis period is from 2008:Q3 to 2010:Q2 $* * *, * *, *$ correspond to one, five, and ten percent levels of significance, respectively.

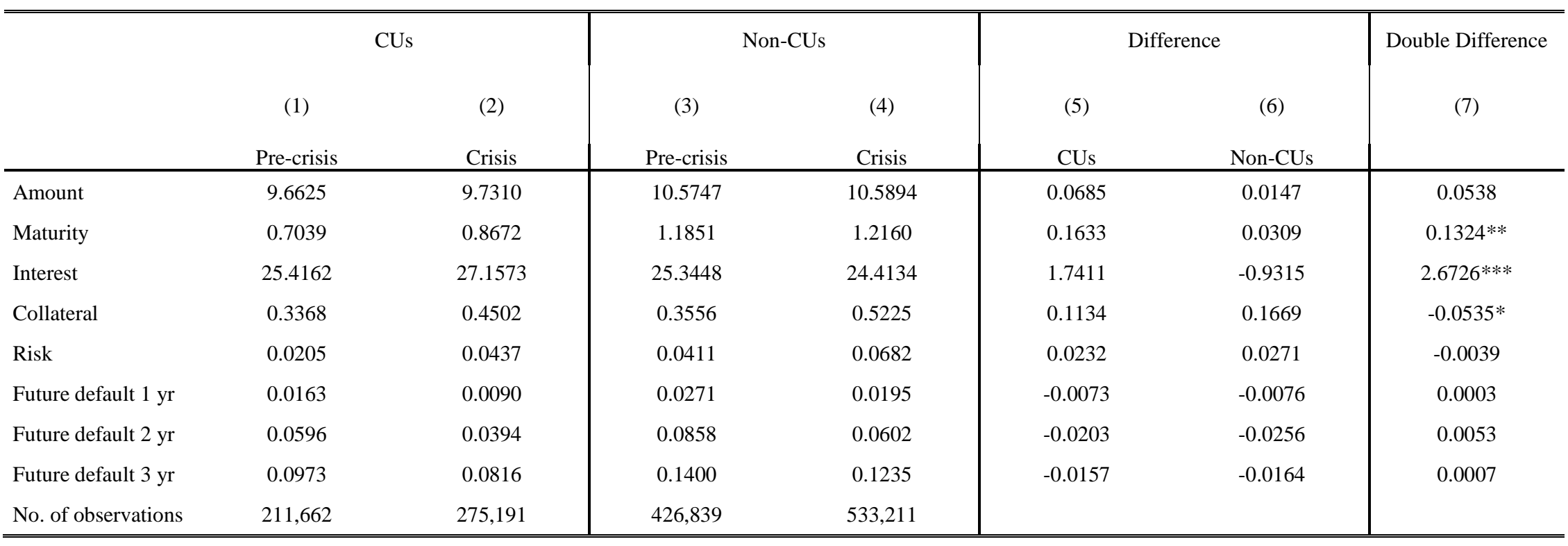


Table 4

\section{Intensive Margin Analysis}

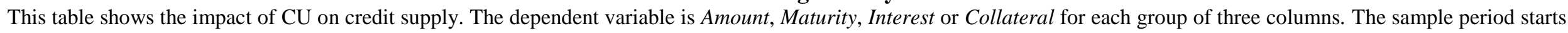
in 2006:Q3 and ends in 2010:Q2. All specifications account for firms that borrow from at least one CU and from one non-CU (foreign, private domestic, or government-owned) in the pre-crisis and in the crisis periods. All regressions are estimated using OLS. Standard errors are clustered on the bank level. Standard errors appear in parentheses, and ***, **, * correspond to one, five, and ten percent levels of significance, respectively.

\begin{tabular}{|c|c|c|c|c|c|c|c|c|c|c|c|c|}
\hline \multirow[t]{2}{*}{ Variable name } & \multicolumn{3}{|c|}{ Amount } & \multicolumn{3}{|c|}{ Maturity } & \multicolumn{3}{|c|}{ Interest } & \multicolumn{3}{|c|}{ Collateral } \\
\hline & $(1)$ & (2) & (3) & $(4)$ & (5) & (6) & (7) & (8) & (9) & (10) & (11) & (12) \\
\hline Crisis & $\begin{array}{c}0.032 \\
(0.054)\end{array}$ & & & $\begin{array}{c}0.026 \\
(0.062)\end{array}$ & & & $\begin{array}{c}-0.365 \\
(0.780)\end{array}$ & & & $\begin{array}{c}0.177 * * * \\
(0.025)\end{array}$ & & \\
\hline CU*Crisis & $\begin{array}{c}0.032 \\
(0.058)\end{array}$ & $\begin{array}{l}0.086^{*} \\
(0.047)\end{array}$ & $\begin{array}{c}0.172 * * * \\
(0.063)\end{array}$ & $\begin{array}{c}0.053 \\
(0.072)\end{array}$ & $\begin{array}{l}0.104^{*} \\
(0.060)\end{array}$ & $\begin{array}{c}0.234 * * * \\
(0.050)\end{array}$ & $\begin{array}{c}2.466 * * * \\
(0.813)\end{array}$ & $\begin{array}{c}2.224 * * * \\
(0.646)\end{array}$ & $\begin{array}{c}1.661 * * \\
(0.794)\end{array}$ & $\begin{array}{c}-0.063 * * \\
(0.026)\end{array}$ & $\begin{array}{c}-0.057 * * * \\
(0.021)\end{array}$ & $\begin{array}{r}-0.060 * * \\
(0.015)\end{array}$ \\
\hline Size & & & $\begin{array}{c}0.455^{* * * *} \\
(0.094)\end{array}$ & & & $\begin{array}{c}0.153 * * \\
(0.076)\end{array}$ & & & $\begin{array}{c}-0.034 \\
(1.887)\end{array}$ & & & $\begin{array}{c}0.052 * * * \\
(0.015)\end{array}$ \\
\hline Liquid assets & & & $\begin{array}{c}-0.942 * * * \\
(0.135)\end{array}$ & & & $\begin{array}{c}-0.298^{*} \\
(0.169)\end{array}$ & & & $\begin{array}{c}-4.691 * * * \\
(1.631)\end{array}$ & & & $\begin{array}{c}-0.097 \\
(0.062)\end{array}$ \\
\hline NPL & & & $\begin{array}{c}0.100 \\
(0.345)\end{array}$ & & & $\begin{array}{c}0.394 \\
(0.382)\end{array}$ & & & $\begin{array}{c}12.399 * \\
(6.577)\end{array}$ & & & $\begin{array}{l}-0.131 \\
(0.149)\end{array}$ \\
\hline Fixed assets & & & $\begin{array}{c}-0.807 * * * \\
(0.285)\end{array}$ & & & $\begin{array}{c}1.127 * * * \\
(0.397)\end{array}$ & & & $\begin{array}{l}-4.920 \\
(3.486)\end{array}$ & & & $\begin{array}{l}-0.166 \\
(0.104)\end{array}$ \\
\hline Deposits & & & $\begin{array}{c}0.477 \\
(0.304)\end{array}$ & & & $\begin{array}{c}0.135 \\
(0.286)\end{array}$ & & & $\begin{array}{c}7.668 * * \\
(3.385)\end{array}$ & & & $\begin{array}{l}-0.074 \\
(0.106)\end{array}$ \\
\hline Equity & & & $\begin{array}{c}0.399 \\
(0.479)\end{array}$ & & & $\begin{array}{l}-0.315 \\
(0.425)\end{array}$ & & & $\begin{array}{c}0.344 \\
(5.096)\end{array}$ & & & $\begin{array}{c}0.187 \\
(0.119)\end{array}$ \\
\hline ROE & & & $\begin{array}{c}0.056 \\
(0.037)\end{array}$ & & & $\begin{array}{l}-0.010 \\
(0.026)\end{array}$ & & & $\begin{array}{c}1.421 * * * \\
(0.437)\end{array}$ & & & $\begin{array}{l}-0.002 \\
(0.007)\end{array}$ \\
\hline Bank FE & Yes & Yes & No & Yes & Yes & No & Yes & Yes & No & Yes & Yes & No \\
\hline Firm-Time FE & No & Yes & Yes & No & Yes & Yes & No & Yes & Yes & No & Yes & Yes \\
\hline Firm-Bank FE & No & No & Yes & No & No & Yes & No & No & Yes & No & No & Yes \\
\hline Observations & $1,446,903$ & $1,446,903$ & $1,446,903$ & $1,446,903$ & $1,446,903$ & $1,446,903$ & $1,446,903$ & $1,446,903$ & $1,446,903$ & $1,446,903$ & $1,446,903$ & $1,446,903$ \\
\hline R-squared & 0.118 & 0.559 & 0.793 & 0.231 & 0.511 & 0.838 & 0.200 & 0.514 & 0.746 & 0.226 & 0.549 & 0.764 \\
\hline
\end{tabular}


Table 5

Risk \& Loan Performance

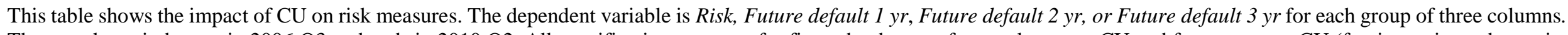
The sample period starts in 2006:Q3 and ends in 2010:Q2. All specifications account for firms that borrow from at least one CU and from one non-CU (foreign, private domestic, or government-owned) in the pre-crisis and in the crisis periods. All regressions are estimated using OLS. All regressions include a constant, and standard errors are clustered on bank level. Standard errors appear in parentheses, and $* * *, * *, *$ correspond to one, five, and ten percent levels of significance, respectively.

\begin{tabular}{|c|c|c|c|c|c|c|c|c|c|c|c|c|}
\hline \multirow[t]{2}{*}{ Variable name } & \multicolumn{3}{|c|}{ Risk } & \multicolumn{3}{|c|}{ Future default 1 yr } & \multicolumn{3}{|c|}{ Future default $2 y r$} & \multicolumn{3}{|c|}{ Future default $3 y r$} \\
\hline & $(1)$ & (2) & (3) & $(4)$ & (5) & $(6)$ & $(7)$ & $(8)$ & (9) & $(10)$ & $(11)$ & $(12)$ \\
\hline Crisis & $\begin{array}{c}0.026 * * * \\
(0.004)\end{array}$ & & & $\begin{array}{c}-0.010 * * * \\
(0.002)\end{array}$ & & & $\begin{array}{c}-0.032 * * * \\
(0.005)\end{array}$ & & & $\begin{array}{c}-0.027 * * * \\
(0.004)\end{array}$ & & \\
\hline CU*Crisis & $\begin{array}{c}-0.002 \\
(0.004)\end{array}$ & $\begin{array}{c}-0.007 * * * \\
(0.003)\end{array}$ & $\begin{array}{c}-0.020 * * * \\
(0.003)\end{array}$ & $\begin{array}{c}0.002 \\
(0.002)\end{array}$ & $\begin{array}{c}0.002 \\
(0.002)\end{array}$ & $\begin{array}{c}0.006 * * * \\
(0.001)\end{array}$ & $\begin{array}{c}0.012 * * \\
(0.005)\end{array}$ & $\begin{array}{c}0.008 \\
(0.005)\end{array}$ & $\begin{array}{c}0.014 * * * \\
(0.002)\end{array}$ & $\begin{array}{c}0.012 \\
(0.004)\end{array}$ & $\begin{array}{c}0.004 \\
(0.005)\end{array}$ & $\begin{array}{c}0.007 * * * \\
(0.001)\end{array}$ \\
\hline Size & & & $\begin{array}{l}-0.003 \\
(0.005)\end{array}$ & & & $\begin{array}{c}0.003 \\
(0.003)\end{array}$ & & & $\begin{array}{c}0.004 \\
(0.004)\end{array}$ & & & $\begin{array}{c}0.002 \\
(0.002)\end{array}$ \\
\hline Liquid assets & & & $\begin{array}{c}-0.030 * * * \\
(0.011)\end{array}$ & & & $\begin{array}{l}-0.001 \\
(0.003)\end{array}$ & & & $\begin{array}{c}-0.000 \\
(0.005)\end{array}$ & & & $\begin{array}{c}0.019 * * * \\
(0.005)\end{array}$ \\
\hline NPL & & & $\begin{array}{c}0.083 * * * \\
(0.029)\end{array}$ & & & $\begin{array}{l}-0.006 \\
(0.012)\end{array}$ & & & $\begin{array}{l}-0.029 \\
(0.020)\end{array}$ & & & $\begin{array}{c}0.031 \\
(0.025)\end{array}$ \\
\hline Fixed assets & & & $\begin{array}{l}0.047 * \\
(0.026)\end{array}$ & & & $\begin{array}{c}-0.023 * * \\
(0.009)\end{array}$ & & & $\begin{array}{c}-0.057 * * * \\
(0.015)\end{array}$ & & & $\begin{array}{c}-0.037 * * \\
(0.018)\end{array}$ \\
\hline Deposits & & & $\begin{array}{c}0.018 \\
(0.013)\end{array}$ & & & $\begin{array}{c}-0.011 \\
(0.007)\end{array}$ & & & $\begin{array}{c}-0.018^{* *} \\
(0.009)\end{array}$ & & & $\begin{array}{l}-0.015 \\
(0.010)\end{array}$ \\
\hline Equity & & & $\begin{array}{c}-0.040 * * \\
(0.020)\end{array}$ & & & $\begin{array}{l}-0.016 \\
(0.012)\end{array}$ & & & $\begin{array}{c}0.009 \\
(0.013)\end{array}$ & & & $\begin{array}{c}0.015 \\
(0.013)\end{array}$ \\
\hline ROE & & & $\begin{array}{l}-0.002 \\
(0.002)\end{array}$ & & & $\begin{array}{l}0.002 * \\
(0.001)\end{array}$ & & & $\begin{array}{l}-0.002 \\
(0.001)\end{array}$ & & & $\begin{array}{c}0.003 * * \\
(0.001)\end{array}$ \\
\hline Bank FE & Yes & Yes & No & Yes & Yes & No & Yes & Yes & No & Yes & Yes & No \\
\hline Firm-Time FE & No & Yes & Yes & No & Yes & Yes & No & Yes & Yes & No & Yes & Yes \\
\hline Firm-Bank FE & No & No & Yes & No & No & Yes & No & No & Yes & No & No & Yes \\
\hline Observations & $1,446,903$ & $1,446,903$ & $1,446,903$ & $1,446,903$ & $1,446,903$ & $1,446,903$ & $1,446,903$ & $1,446,903$ & $1,446,903$ & $1,446,903$ & $1,446,903$ & $1,446,903$ \\
\hline R-squared & 0.042 & 0.524 & 0.723 & 0.018 & 0.440 & 0.883 & 0.031 & 0.515 & 0.949 & 0.041 & 0.558 & 0.979 \\
\hline
\end{tabular}


Table 6

\section{Heterogeneous Effect of the Bank Equity Ratio}

This table shows the impact of CU on credit supply depending on the banks' equity ratio. The dependent variable is Amount, Maturity, Interest, Collateral, or Future Default. HighEquity is a dummy variable that takes the value one if equity of bank $b$ is above the median equity ratio of the respective group of banks $(\mathrm{CU}=0$ or CU $=1)$ in quarter $t$, and zero otherwise. The sample period starts in 2006:Q3 and ends in 2010:Q2. All specifications account for firms that borrow from at least one credit union and from one noncredit union (foreign, private domestic, or government-owned) in the pre-crisis and in the crisis periods. All regressions are estimated using OLS. Standard errors are clustered on the bank level. Standard errors appear in parentheses, and ***, **,* correspond to one, five, and ten percent levels of significance, respectively.

\begin{tabular}{|c|c|c|c|c|c|c|c|c|}
\hline Variable name & $\begin{array}{c}\text { Amount } \\
\text { (1) }\end{array}$ & $\begin{array}{c}\text { Maturity } \\
(2)\end{array}$ & $\begin{array}{c}\text { Interest } \\
(3)\end{array}$ & $\begin{array}{c}\text { Collateral } \\
(4)\end{array}$ & $\begin{array}{c}\text { Risk } \\
(5)\end{array}$ & $\begin{array}{c}\text { Future default } 1 \text { yr } \\
(6)\end{array}$ & $\begin{array}{c}\text { Future default } 2 y r \\
\text { (7) }\end{array}$ & $\begin{array}{c}\text { Future default } 3 \text { yr } \\
(8)\end{array}$ \\
\hline HighEquity & $\begin{array}{l}0.115^{*} \\
(0.060)\end{array}$ & $\begin{array}{l}-0.047 \\
(0.034)\end{array}$ & $\begin{array}{l}1.521^{*} \\
(0.808)\end{array}$ & $\begin{array}{c}0.007 \\
(0.022)\end{array}$ & $\begin{array}{c}0.003 \\
(0.003)\end{array}$ & $\begin{array}{c}0.000 \\
(0.001)\end{array}$ & $\begin{array}{c}-0.005^{* *} \\
(0.002)\end{array}$ & $\begin{array}{l}-0.002 \\
(0.002)\end{array}$ \\
\hline CU*Crisis & $\begin{array}{c}0.072 \\
(0.073)\end{array}$ & $\begin{array}{l}0.192 * * \\
(0.075)\end{array}$ & $\begin{array}{c}0.749 \\
(1.060)\end{array}$ & $\begin{array}{c}-0.061 * * * \\
(0.015)\end{array}$ & $\begin{array}{c}-0.020 * * * \\
(0.004)\end{array}$ & $\begin{array}{c}0.005 * * * \\
(0.001)\end{array}$ & $\begin{array}{c}0.016 * * * \\
(0.002)\end{array}$ & $\begin{array}{c}0.010 * * * \\
(0.002)\end{array}$ \\
\hline HighEquity*Crisis & $\begin{array}{l}-0.136 \\
(0.095)\end{array}$ & $\begin{array}{c}0.066 \\
(0.057)\end{array}$ & $\begin{array}{l}-2.224 * \\
(1.326)\end{array}$ & $\begin{array}{l}-0.056^{*} \\
(0.030)\end{array}$ & $\begin{array}{l}-0.006 \\
(0.005)\end{array}$ & $\begin{array}{l}-0.002 \\
(0.002)\end{array}$ & $\begin{array}{c}0.001 \\
(0.004)\end{array}$ & $\begin{array}{c}0.002 \\
(0.003)\end{array}$ \\
\hline CU*HighEquity & $\begin{array}{l}-0.106^{*} \\
(0.055)\end{array}$ & $\begin{array}{l}-0.002 \\
(0.050)\end{array}$ & $\begin{array}{l}-0.919 \\
(0.824)\end{array}$ & $\begin{array}{c}0.012 \\
(0.025)\end{array}$ & $\begin{array}{l}-0.001 \\
(0.004)\end{array}$ & $\begin{array}{c}0.001 \\
(0.002)\end{array}$ & $\begin{array}{c}0.007 * * * \\
(0.002)\end{array}$ & $\begin{array}{c}0.002 \\
(0.002)\end{array}$ \\
\hline CU*HighEquity*Crisis & $\begin{array}{c}0.231 * * * \\
(0.084)\end{array}$ & $\begin{array}{c}0.061 \\
(0.093)\end{array}$ & $\begin{array}{l}2.399 * \\
(1.343)\end{array}$ & $\begin{array}{c}0.017 \\
(0.033)\end{array}$ & $\begin{array}{c}0.004 \\
(0.006)\end{array}$ & $\begin{array}{c}0.001 \\
(0.002)\end{array}$ & $\begin{array}{l}-0.004 \\
(0.004)\end{array}$ & $\begin{array}{l}-0.005^{*} \\
(0.003)\end{array}$ \\
\hline Size & $\begin{array}{c}0.461 * * * \\
(0.079)\end{array}$ & $\begin{array}{l}0.162^{* *} \\
(0.080)\end{array}$ & $\begin{array}{c}0.381 \\
(1.591)\end{array}$ & $\begin{array}{c}0.050^{* * *} \\
(0.016)\end{array}$ & $\begin{array}{c}0.000 \\
(0.005)\end{array}$ & $\begin{array}{c}0.004 \\
(0.003)\end{array}$ & $\begin{array}{c}0.003 \\
(0.004)\end{array}$ & $\begin{array}{c}0.000 \\
(0.002)\end{array}$ \\
\hline Liquid assets & $\begin{array}{c}-0.924 * * * \\
(0.146)\end{array}$ & $\begin{array}{l}-0.348 * \\
(0.178)\end{array}$ & $\begin{array}{c}-4.622 * * * \\
(1.548)\end{array}$ & $\begin{array}{l}-0.079 \\
(0.064)\end{array}$ & $\begin{array}{c}-0.032 * * * \\
(0.011)\end{array}$ & $\begin{array}{l}-0.002 \\
(0.003)\end{array}$ & $\begin{array}{c}0.001 \\
(0.005)\end{array}$ & $\begin{array}{c}0.020 * * * \\
(0.005)\end{array}$ \\
\hline NPL & $\begin{array}{c}0.108 \\
(0.348)\end{array}$ & $\begin{array}{c}0.431 \\
(0.397)\end{array}$ & $\begin{array}{c}12.698 * * \\
(6.292)\end{array}$ & $\begin{array}{l}-0.141 \\
(0.147)\end{array}$ & $\begin{array}{c}0.086 * * * \\
(0.030)\end{array}$ & $\begin{array}{l}-0.004 \\
(0.012)\end{array}$ & $\begin{array}{l}-0.029 \\
(0.021)\end{array}$ & $\begin{array}{c}0.029 \\
(0.025)\end{array}$ \\
\hline Fixed assets & $\begin{array}{l}-0.556^{*} \\
(0.288)\end{array}$ & $\begin{array}{c}0.917 * * \\
(0.367)\end{array}$ & $\begin{array}{l}-2.981 \\
(2.881)\end{array}$ & $\begin{array}{l}-0.018 \\
(0.106)\end{array}$ & $\begin{array}{c}0.037 \\
(0.024)\end{array}$ & $\begin{array}{c}-0.028 * * * \\
(0.009)\end{array}$ & $\begin{array}{c}-0.052 * * * \\
(0.012)\end{array}$ & $\begin{array}{c}-0.031 * * \\
(0.015)\end{array}$ \\
\hline Deposits & $\begin{array}{c}0.337 \\
(0.228)\end{array}$ & $\begin{array}{c}0.282 \\
(0.270)\end{array}$ & $\begin{array}{c}6.957 * * * \\
(2.642)\end{array}$ & $\begin{array}{c}-0.176^{* *} \\
(0.083)\end{array}$ & $\begin{array}{l}0.027 * \\
(0.014)\end{array}$ & $\begin{array}{c}-0.007 \\
(0.006)\end{array}$ & $\begin{array}{c}-0.023 * * * \\
(0.008)\end{array}$ & $\begin{array}{c}-0.020 * * * * \\
(0.007)\end{array}$ \\
\hline ROE & $\begin{array}{c}0.052 \\
(0.032)\end{array}$ & $\begin{array}{l}-0.009 \\
(0.023)\end{array}$ & $\begin{array}{c}1.237 * * * \\
(0.394)\end{array}$ & $\begin{array}{c}-0.004 \\
(0.009)\end{array}$ & $\begin{array}{l}-0.003 \\
(0.002)\end{array}$ & $\begin{array}{c}0.001 \\
(0.001)\end{array}$ & $\begin{array}{c}-0.002 \\
(0.001)\end{array}$ & $\begin{array}{c}0.003 * * * \\
(0.001)\end{array}$ \\
\hline Firm-Time FE & Yes & Yes & Yes & Yes & Yes & Yes & Yes & Yes \\
\hline Firm-Bank FE & Yes & Yes & Yes & Yes & Yes & Yes & Yes & Yes \\
\hline $\begin{array}{l}\text { Observations } \\
\text { R-squared }\end{array}$ & $\begin{array}{c}1,446,903 \\
0.793\end{array}$ & $\begin{array}{c}1,446,903 \\
0.838\end{array}$ & $\begin{array}{c}1,446,903 \\
0.747\end{array}$ & $\begin{array}{c}1,446,903 \\
0.765\end{array}$ & $\begin{array}{c}1,446,903 \\
0.723\end{array}$ & $\begin{array}{c}1,446,903 \\
0.883\end{array}$ & $\begin{array}{c}1,446,903 \\
0.949\end{array}$ & $\begin{array}{c}1,446,903 \\
0.979\end{array}$ \\
\hline
\end{tabular}


Table 7

Labor Market: Descriptive Statistics and Difference-in-Difference Analysis

This table shows our descriptive statistics and difference-in-difference (DD) analysis for labor market. We test the difference of means between firms that had above-median lending from CUs (HighShare) and below median lending from CUs (LowShare). Our sample of firms is classified into micro, small, and medium firms. Our sample includes firms that borrow from at least one $\mathrm{CU}$ and one non-CU (foreign, private domestic, or government owned) in the pre-crisis and the crisis periods. We aggregate the data into a single data point (based on averages) for each of the groups of interest and compute double differences. The data span the quarters of 2007:Q3 to 2010:Q2 where the pre-crisis period ranges from 2007:Q3 to 2008:Q2 and the crisis period is from 2008:Q3 to 2010:Q2.***,**,* correspond to one, five, and ten percent levels of significance, respectively.

a) Descriptive Statistics

\begin{tabular}{|c|c|c|c|c|c|}
\hline Variable name & Mean & Sd. & Min & Median & Max \\
\hline Employment & 2.72 & 1.16 & 0.69 & 2.64 & 5.52 \\
\hline Employees & 29.69 & 43.17 & 1.00 & 13.00 & 249.00 \\
\hline Wage (log) & 9.17 & 1.49 & 0.00 & 9.12 & 13.64 \\
\hline Wage in BRL & $26,362.62$ & $45,782.51$ & 0.00 & $9,148.48$ & $839,145.10$ \\
\hline No. of observations & & & & & 439,211 \\
\hline
\end{tabular}

\begin{tabular}{|c|c|c|c|c|c|c|c|}
\hline & & High S & & & Low $\mathrm{S}$ & & \\
\hline & (1) & (2) & (3) & (4) & (5) & (6) & (7) \\
\hline & Pre-crisis & Crisis & Difference & Pre-crisis & Crisis & Difference & Double Difference \\
\hline \multicolumn{8}{|l|}{ All firms } \\
\hline Employment & 2.3479 & 2.4091 & 0.0612 & 2.6426 & 2.7103 & 0.0677 & -0.007 \\
\hline Wages & 8.6032 & 8.8187 & 0.2155 & 8.9835 & 9.2091 & 0.2256 & -0.010 \\
\hline No. of observations & 31,995 & 35,903 & & 29,512 & 34,861 & & 132,271 \\
\hline \multicolumn{8}{|l|}{ Micro firms } \\
\hline Employment & 1.5521 & 1.5539 & 0.0018 & 1.6385 & 1.6417 & 0.0032 & -0.0014 \\
\hline Wages & 7.6131 & 7.7490 & 0.1359 & 7.7472 & 7.8899 & 0.1426 & -0.0068 \\
\hline No. of observations & 17,469 & 18,596 & & 12,751 & 14,279 & & 63,095 \\
\hline \multicolumn{8}{|l|}{ Small firms } \\
\hline Employment & 2.9678 & 2.9866 & 0.0188 & 3.0272 & 3.0428 & 0.0157 & 0.0032 \\
\hline Wages & 9.4243 & 9.5944 & 0.1701 & 9.5017 & 9.6730 & 0.1713 & -0.0012 \\
\hline No. of observations & 11,386 & 13,491 & & 12,682 & 15,128 & & 52,687 \\
\hline \multicolumn{8}{|c|}{ Medium firms } \\
\hline Employment & 4.5278 & 4.5350 & 0.0073 & 4.5853 & 4.5854 & 0.0001 & 0.0072 \\
\hline Wages & 11.1342 & 11.2892 & 0.1549 & 11.2371 & 11.3762 & 0.1391 & 0.0159 \\
\hline No. of observations & 3,140 & 3,816 & & 4,079 & 5,454 & & 16,489 \\
\hline
\end{tabular}




\section{Table 8}

\section{Labor Market Effects: Employment}

This table shows the impact of CU lending on the real economy. The dependent variable is Employment. We run separate regressions for micro, small, and medium firms; the results for each category are reported in each group of three columns. The sample period starts in 2007:Q3 and ends in 2010:Q2 where the pre-crisis period ranges from 2007:Q3 to 2008:Q2 and the crisis period is from 2008:Q3 to 2010:Q2. All specifications account for firms that borrow from at least one CU and from one non-CU (foreign, private domestic, or government-owned) in the pre-crisis and in the crisis periods. All regressions are estimated using OLS. Standard errors are clustered on the firm level. Standard errors appear in parentheses, and ***,**,* correspond to one, five, and ten percent levels of significance, respectively.

\begin{tabular}{|c|c|c|c|c|c|c|c|c|c|}
\hline \multirow[t]{2}{*}{ Firm size } & \multicolumn{3}{|c|}{ Micro firms } & \multicolumn{3}{|c|}{ Small firms } & \multicolumn{3}{|c|}{ Medium firms } \\
\hline & $(1)$ & (2) & (3) & (4) & (5) & $(6)$ & $(7)$ & (8) & $(9)$ \\
\hline \multirow[t]{2}{*}{ Crisis } & 0.003 & $0.036 * * *$ & & $0.016^{* *}$ & $0.099 * * *$ & & 0.000 & $0.136 * * *$ & \\
\hline & $(0.007)$ & $(0.005)$ & & $(0.007)$ & $(0.005)$ & & $(0.013)$ & $(0.009)$ & \\
\hline \multirow[t]{2}{*}{ HighShare } & $-0.086 * * *$ & & & $-0.059 * * *$ & & & $-0.058 * *$ & & \\
\hline & $(0.012)$ & & & $(0.012)$ & & & $(0.022)$ & & \\
\hline \multirow[t]{2}{*}{ HighShare*Crisis } & -0.001 & $0.021 * * *$ & $0.023 * * *$ & 0.003 & 0.003 & 0.004 & 0.007 & -0.014 & -0.015 \\
\hline & $(0.010)$ & $(0.007)$ & $(0.007)$ & $(0.010)$ & $(0.007)$ & $(0.008)$ & $(0.019)$ & $(0.013)$ & $(0.013)$ \\
\hline Firm FE & No & Yes & Yes & No & Yes & Yes & No & Yes & Yes \\
\hline Time FE & No & No & Yes & No & No & Yes & No & No & Yes \\
\hline Observations & 63,095 & 63,095 & 63,095 & 52,687 & 52,687 & 52,687 & 16,489 & 16,489 & 16,489 \\
\hline R-squared & 0.007 & 0.779 & 0.792 & 0.005 & 0.787 & 0.810 & 0.004 & 0.803 & 0.830 \\
\hline
\end{tabular}


Table 9

Labor Market Effects: Wages

This table shows the impact of CU lending on the real economy. The dependent variable is Wages. We run separate regressions for micro, small, and medium firms; the results for each category are reported in each group of three columns. The sample period starts in 2007:Q3 and ends in 2010:Q2 where the pre-crisis period ranges from 2007:Q3 to 2008:Q2 and the crisis period is from 2008:Q3 to 2010:Q2. All specifications account for firms that borrow from at least one CU and from one non-CU (foreign, private domestic, or government owned) in the pre-crisis and in the crisis periods. All regressions are estimated using OLS. Standard errors are clustered on the firm level. Standard errors appear in parentheses, and ***,**,* correspond to one, five, and ten percent levels of significance, respectively.

\begin{tabular}{|c|c|c|c|c|c|c|c|c|c|}
\hline \multirow[t]{2}{*}{ Firm size } & \multicolumn{3}{|c|}{ Micro firms } & \multicolumn{3}{|c|}{ Small firms } & \multicolumn{3}{|c|}{ Medium firms } \\
\hline & (1) & (2) & (3) & (4) & (5) & $(6)$ & (7) & $(8)$ & (9) \\
\hline \multirow[t]{2}{*}{ Crisis } & $0.143 * * *$ & $0.180 * * *$ & & $0.171 * * *$ & $0.257 * * *$ & & $0.139 * * *$ & $0.286^{* * *}$ & \\
\hline & $(0.013)$ & $(0.011)$ & & $(0.009)$ & $(0.006)$ & & $(0.017)$ & $(0.010)$ & \\
\hline \multirow[t]{2}{*}{ HighShare } & $-0.134 * * *$ & & & $-0.077 * * *$ & & & $-0.103 * * *$ & & \\
\hline & $(0.021)$ & & & $(0.017)$ & & & $(0.031)$ & & \\
\hline \multirow[t]{2}{*}{ HighShare*Crisis } & -0.007 & $0.032 * *$ & $0.032 * *$ & -0.001 & -0.001 & -0.003 & 0.016 & -0.009 & -0.012 \\
\hline & $(0.018)$ & $(0.015)$ & $(0.015)$ & $(0.013)$ & (0.009) & (0.009) & $(0.024)$ & $(0.015)$ & $(0.015)$ \\
\hline Firm FE & No & Yes & Yes & No & Yes & Yes & No & Yes & Yes \\
\hline Time FE & No & No & Yes & No & No & Yes & No & No & Yes \\
\hline Observations & 63,095 & 63,095 & 63,095 & 52,687 & 52,687 & 52,687 & 16,489 & 16,489 & 16,489 \\
\hline R-squared & 0.011 & 0.749 & 0.753 & 0.024 & 0.842 & 0.855 & 0.022 & 0.875 & 0.892 \\
\hline
\end{tabular}

